\title{
Upaya Meningkatkan Hasil Belajar Siswa dengan Menggunakan Strategi Omaggio pada Mata Pelajaran Bahasa Indonesia Tingkat Madrasah Ibtidaiyah
}

\author{
Iwan Darmawan \\ Institut Agama Islam Darussalam (IAID), Ciamis-Jawa Barat \\ Email: iwan.darmawan10@gmail.com \\ Lilis Nurteti \\ Institut Agama Islam Darussalam (IAID), Ciamis-Jawa Barat \\ Sri Meidawaty \\ Institut Agama Islam Darussalam (IAID), Ciamis-Jawa Barat
}

\begin{abstract}
This research is motivated by the low learning outcomes of students of grade V Madrasah Ibtidaiyah Thoriqun Najah on learning Indonesian language subject matter elements. In an effort to improve student learning outcomes, researchers used the "Omaggio strategy". Classroom management can be done by approach through variations of learning strategies. Learning strategy has a very big role in the learning process. Such learning strategies include "Omaggio strategy". The objectives of this research are: 1) To improve the ability of teachers in preparing the Lesson Plans on Indonesian subjects listening to the subject matter elements by using "Omaggio strategy", 2) To improve the ability of teachers in the process of learning the language Indonesia aspects of listening to the subject elements of the story by using "Omaggio strategy", 3) To improve student learning outcomes on the subjects of Indonesian language aspects of listening to the subject elements of the story by using "Omaggio strategy". The method used is Classroom Action Research Method model Kurt Lewin. Data collection techniques used are observation, test or assessment techniques and description analysis techniques. After conducting the research, the final result data can be obtained as follows: 1) the ability of teachers in designing the learning aspect listening Indonesian language with an average value of 96.15. 2) the skills of teachers in the implementation of learning Indonesian listening aspects with an average value of 97.22. 3) Students' learning outcomes on Indonesian subjects listened to an average score of 82.19. This proves that "Omaggio strategy" can improve student learning outcomes in Indonesian subjects listening aspect of the story elements in class V Madrasah Ibtidaiyah Thoriqun Najah Sukadana District Ciamis Regency. The results of the analysis show that the proposed hypothesis is acceptable.
\end{abstract}

Keywords: Omaggio strategy, listening, language, learning outcomes 


\section{PENDAHULUAN}

Masyarakat dan bahasa merupakan dua hal yang memiliki hubungan yang sangat erat. Tidak ada masyarakat tanpa bahasa, begitu pula sebaliknya tidak akan ada bahasa tanpa masyarakat. Bahasa merupakan salah satu sarana berinteraksi dalam kehidupan bermasyarakat. Interaksi dalam masyarakat tidak akan terlaksana dengan baik tanpa menggunakan bahasa. Hal itu sejalan dengan fungsi bahasa secara umum sebagai alat komunikasi sosial. Oleh karena itu, kelangsungan komunikasi dalam masyarakat sangat ditunjang oleh keberadaan bahasa (Soeparno, 2002: 5).

Komunikasi yang baik didukung oleh keterampilan berbahasa, baik lisan maupun tulisan. Komunikasi yang baik tersebut akan berjalan jika pesan dari pembicara dapat dipahami oleh penyimak sesuai dengan maksud yang disampaikan. Penggunaan bahasa dalam komunikasi juga dapat mencerminkan pikiran seseorang. Semakin terampil seseorang berbahasa, semakin cerah dan jelas pula jalan pikirannya. Keterampilan berbahasa hanya dapat diperoleh dan dikuasai dengan praktik dan banyak latihan. Melatih keterampilan berbahasa berarti pula melatih keterampilan berpikir (Tarigan, 2008: 2-3).

Keterampilan berbahasa (language arts, language skills) dalam kurikulum di sekolah mencakup empat aspek, yaitu: (1) keterampilan menyimak (listening skills), (2) keterampilan berbicara (speaking skills), (3) keterampilan membaca (reading skills), dan (4) keterampilan menulis (writing skills) (Tarigan, 2008: 2). Keempat keterampilan berbahasa ini tidak bisa dipisahkan. Dari keempat keterampilan berbahasa tersebut, keterampilan menyimak adalah keterampilan yang paling awal diperoleh dan merupakan dasar dalam aktivitas berkomunikasi.

Selain merupakan salah satu keterampilan yang paling mendasar dalam aktivitas berkomunikasi, keterampilan menyimak merupakan kegiatan yang bersifat reseptif. Hal itu dikarenakan selama berlangsungnya kegiatan komunikasi, penyimak aktif menerima, menangkap, memahami, dan mengingat ujaran yang diterimanya. Menyimak juga dapat dikatakan sebagai kegiatan aktif reseptif karena secara fisik, penyimak menerima pesan-pesan atau informasi-informasi melalui pendengaran, tetapi sebenarnya penyimak aktif mencerna dan mengolah pesan-pesan tersebut agar dapat memahami maksudnya (Sutari, 2000: 6). Menyimak merupakan keterampilan berbahasa yang tidak dapat dilepaskan dari kehidupan manusia sehari-hari, baik di lingkungan formal maupun informal. Dalam lingkungan formal yaitu sekolah, kegiatan menyimak dilakukan dalam interaksi pembelajaran. Dalam hal ini, menyimak sangat efektif dalam penyampaian pesan-pesan yang mendidik. Pesan-pesan yang disampaikan dalam kegiatan menyimak dapat berupa nilai-nilai yang berguna sebagai muatan moral. 


\section{BESTARI}

Vol. 16, No. 2, 2019

p-ISSN 1907-1337; e-ISSN 2807-6532

Madrasah Ibtidaiyah Thoriqun Najah merupakan salah satu dari beberapa lembaga pendidikan dasar berbasis Islam yang ada di Kecamatan Sukadana, Kabupaten Ciamis, Provinsi Jawa Barat. Sebagai lembaga pendidikan islam, tidak lepas dari tujuan yang diharapkan. Adapun tujuan Lembaga pendidikan Islam (madrasah) tersebut, yakni: (1) membantu pengembangan individu, (2) meningkatkan pemahaman terhadap aturan-aturan sosial dan moral, dan (3) mentransmisikan pengetahuan (Halstead dalam Wahid, 2008: 73).

Sesuai dengan tujuan tersebut, pembelajaran di madrasah layaknya paling optimal dalam menyampaikan nilai-nilai yang baik, termasuk dalam pembelajaran bahasa Indonesia. Tujuan pengajaran bahasa Indonesia di SD secara umum mengacu pada kemampuan memahami bahasa Indonesia dari segi bentuk, makna, dan fungsi serta menggunakannya secara tepat dan kreatif untuk bermacam-macam tujuan, keperluan, dan keadaan secara lisan ataupun tertulis (Resmini, 2002: 5).

Namun kenyataannya tenaga pendidik di MIS Thoriqun Najah cenderung menggunakan cara tradisional yaitu ceramah dalam pembelajaran bahasa Indonesia aspek menyimak. Pembelajaran menyimak tersebut dilakukan di ruang kelas karena belum ada labolatorium bahasa yang bisa dimanfaatkan di sekolah ini. Dilihat dari hasil belajar siswa dalam pembelajaran bahasa Indonesia aspek menyimak hanya 8 orang siswa yang nilainya mencapai KKM 70, sedangkan 13 orang siswa lainnya masih berada di bawah nilai KKM (Sumber: Hasil wawancara dengan wali kelas V MIS Thoriqun Najah pada tanggal 16 Februari 2017).

Keterbatasan sarana pendukung pembelajaran dan kompetensi guru di Madrasah Ibtidaiyah Thoriqun Najah menjadikan menyimak kurang mendapatkan perhatian. Hal itu bertentangan dengan Kurikulum Tingkat Satuan Pendidikan (KTSP) yang menjadikan menyimak sebagai bagian dari pembelajaran bahasa, yaitu pada mata pelajaran bahasa Indonesia. Menyimak sebagai kegiatan reseptif atau aktif reseptif perlu dikembangkan karena pada pembelajaran menyimak, siswa tidak hanya terfokus pada teori bahasa, tetapi juga menekankan pada sikap dan pemakaian bahasa yang kontekstual (Hidayah, 2010: 3).

Dalam pembelajaran bahasa Indonesia khususnya menyimak, siswa Madrasah Ibtidaiyah Thoriqun Najah kelas V belum mengenal berbagai macam strategi pembelajaran. Oleh karena itu, sekolah ini layak dijadikan tempat penelitian dalam pembelajaran Bahasa Indonesia dalam aspek menyimak.

Menyimak merupakan salah satu kegiatan pembelajaran yang dapat menyampaikan nilai-nilai sosial dan moral. Selain pertimbangan di atas, pemilihan Madrasah Ibtidaiyah Thoriqun Najah sebagai tempat 
Penelitian Tindakan Kelas, karena belum ada strategi pembelajaran menyimak yang diterapkan di sekolah ini, sehingga pembelajaran menyimak Bahasa Indonesia belum mencapai KKM.

Berbagai macam strategi dapat diterapkan dalam pembelajaran menyimak. Dalam hal ini satu strategi yang akan digunakan oleh peneliti untuk meningkatkan hasil belajar siswa adalah "strategi Omaggio". "Strategi Omaggio" adalah serangkaian langkah-langkah yang digunakan oleh Alice Omaggio Hedley dalam pembelajaran menyimak di sekolah. Langkah-langkah tersebut meliputi: mengecek pemahaman, dikte, menyimak selektif, dan membuat ringkasan. Dengan adanya langkahlangkah tersebut, siswa dibantu untuk dapat memahami bahan simakan dengan baik. (Pujiastuti, 2007: 7)

Pembelajaran menyimak dalam penelitian ini adalah menyimak cerita rakyat. Menyimak cerita rakyat sesuai dengan standar kompetensi (SK) dan kompetensi dasar (KD) dalam Kurikulum Tingkat Satuan Pendidikan di Madrasah Ibtidaiyah kelas V. Pembelajaran menyimak cerita rakyat dalam penelitian ini dilakukan melalui rekaman. Rekaman cerita rakyat yang memuat pesan moral tersebut diperdengarkan kepada siswa yang menerapkan pembelajaran dengan "strategi Omaggio" dalam pembelajaran bahasa Indonesia aspek menyimak cerita rakyat di kelas $\mathrm{V}$ Madrasah Ibtidaiyah Thoriqun Najah.

Berdasarkan uraian di atas maka penulis terinspirasi untuk melakukan Penelitian Tindakan Kelas (PTK) dengan judul: Upaya Meningkatkan Hasil Belajar Siswa dengan Menggunakan Strategi Omaggio Pada Mata Pelajaran Bahasa Indonesia Aspek Menyimak Pokok Bahasan Unsur-unsur Cerita. (Penelitian Tindakan Kelas di Kelas V Madrasah Ibtidaiyah Thoriqun Najah Kecamatan Sukadana Kabupaten Ciamis).

\section{KAJIAN TEORI}

\section{Pembelajaran Bahasa Indonesia}

Bahasa merupakan sarana untuk saling berkomunikasi, saling berbagi pengalaman, saling belajar dari yang lain, serta untuk meningkatkan pengetahuan intelektual dan kesusasteraan merupakan salah satu sarana untuk menuju pemahaman tersebut. Standar kompetensi mata pelajaran bahasa Indonesia adalah program untuk mengembangkan pengetahuan, keterampilan berbahasa, dan sikap positif terhadap bahasa Indonesia, serta menghargai manusia dan nilai-nilai kemanusiaan. (BSNP, 2006: 10)

Menurut Kurikulum Tingkat Satuan Pendikan (KTSP) (Depdiknas, 2006: 18) mengemukakan bahwa, ruang lingkup mata pelajaran bahasa Indonesia mencakup komponen kemampuan barbahasa dan kemampuan bersastra yang meliputi aspek-aspek sebagai berikut: 


\section{BESTARI}

Vol. 16, No. 2, 2019

p-ISSN 1907-1337; e-ISSN 2807-6532

1) Mendengarkan, seperti mendengarkan berita, petunjuk, pengumuman, perintah, dan bunyi atau suara, bunyi bahasa lagu, kaset, pesan, penjelasan, laporan, ceramah, khotbah, pidato, pembicaraan nara sumber, dialog atau percakapan, pengumuman serta perintah yang didengar dengan memberikan respon secara tepat serta mengapresiasi sastra berupa dongeng, cerita anak-anak, cerita rakyat, cerita binatang, puisi anak, syair lagu, pantun dan menonton drama anak.

2) Berbicara, seperti mengungkapkan gagasan dan perasaan , menyampaikan sambutan, dialog, pesan, pengalaman, suatu proses, menceritakan diri sendiri, teman, keluarga, masyarakat, benda, tanaman, binatang, gambar tunggal, gambar seri, kegiatan sehari-hari, peristiwa, tokoh, kesukaan/ketidaksukaan, kegemaran, peraturan, tata petunjuk, dan laporan, serta mengapresiasi dan berekspresi sastra melalui kegiatan menuliskan hasil sastra berupa dongeng cerita anakanak, cerita rakyat, cerita binatang, puisi anak, syair lagu, pantun, dan drama anak.

3) Membaca, seperti membaca huruf, suku kata, kata, kalimat, paragraf, berbagai teks bacaan, denah, petunjuk, tata tertib, pengumuman, kamus, ensiklopedi, serta mengapresiasi dan berekspresi, sastra melalui kegiatan membaca hasil sastra berupa dongeng, cerita anakanak, cerita rakyat, cerita binatang, puisi anak, syair lagu, pantun, dan drama anak.

4) Menulis, seperti menulis karangan naratif dan normatif dengan tulisan rapi dan jelas dengan memerhatikan tujuan dan ragam pembaca, pemakaian ejaan dan tanda baca, dan kosa kata yang tepat dengan menggunakan kalimat tunggal dan kalimat majemuk, serta mengapresiasi dan berekspresi sastra melalui kegiatan menulis hasil sastra berupa cerita dan puisi.

Tujuan pembelajaran bahasa Indonesia menurut (BSNP, 2006:

10) adalah agar siswa memiliki kemampuan diantaranya:

1) Berkomunikasi secara efektif dan efisien sesuai dengan etika yang berlaku, baik secara lisan maupun secara tulisan.

2) Menghargai dan bangga dalam menggunakan bahasa Indonesia sebagai bahasa persatuan dan bahasa Negara.

3) Memahami bahasa Indonesia dan menggunakannya dengan tepat dan kreatif untuk berbagai tujuan.

4) Menggunakan bahasa Indonesia untuk meningkatkan kemampuan intelektual serta kematangan emosional dan sosial.

5) Meningkatkan dan memanfaatkan karya sastra untuk memperluas wawasan, memperhalus budi pekerti serta meningkatkan pengetahuan dan kemampuan berbahasa. 
6) Menghargai dan membanggakan sastra Indonesia sebagai khasanah budaya dan intelektual manusia Indonesia.

\section{Konsep Menyimak}

Landasan teori tentang menyimak berikut ini dijabarkan berdasarkan pengertian menyimak. Mendengar mempunyai makna dapat menangkap suara (bunyi) dengan telinga, sedangkan mendengarkan adalah mendengar sesuatu dengan sungguh-sungguh atau memasang telinga baik-baik untuk mendengar (KBBI Online, 2017). Disadari atau tidak, jika ada bunyi, bunyi tersebut akan ditanggap atau didengar oleh telinga. Proses seperti itu kadang dilakukan tanpa unsur kesengajaan. Proses tersebut merupakan proses mendengar yang terjadi tanpa perencanaan dan datang secara kebetulan. Bunyi-bunyi yang diterima tersebut kadangkala menarik perhatian dan kadang kala tidak.

Menyimak memiliki makna mendengarkan atau memperhatikan baik-baik apa yang dikatakan orang lain. Dalam hal itu, faktor kesengajaan dalam kegiatan menyimak cukup besar daripada mendengarkan karena dalam kegiatan menyimak ada usaha memahami apa yang disimaknya, sedangkan dalam kegiatan mendengarkan tingkatan pemahaman belum dilakukan (Sutari, 2000: 8)

Menyimak juga merupakan kegiatan yang tidak mudah. Menyimak bukanlah kegiatan yang hanya melibatkan telinga, namun juga melibatkan aktivitas otak yang rumit. Para psikolinguis menyebutnya sebagai mental proccesed (Musfiroh, 2004: 5).

Beberapa pengertian di atas memberikan pemahaman bahwa menyimak merupakan proses mental, bukan sekedar kegiatan mendengarkan, melainkan sebagai suatu proses menangkap lambanglambang lisan dengan penuh perhatian, pemahaman, apresiasi, serta interpretasi untuk memperoleh informasi dan menghubungkannya dengan pengetahuan latar belakang yang telah dimiliki si penyimak. Mendengarkan memiliki arti mendengar sesuatu dengan sungguhsungguh karena ada yang menarik perhatian, ada unsur kesengajaan dan sudah melibatkan aktivitas mental, tetapi belum setinggi menyimak.

Kegiatan menyimak dalam penelitian ini adalah proses mendengarkan cerita rakyat dengan penuh perhatian, pemahaman, apresiasi, serta interpretasi yang kemudian dihubungkan dengan pengalaman siswa. Kegiatan menyimak dilakukan melalui rekaman cerita rakyat yang diperdengarkan secara seksama oleh siswa. Dalam kegiatan menyimak tersebut, diperlukan pemahaman siswa tentang cerita rakyat.

Adapun Standar Kompetensi Lulusan (SKL) kemampuan menyimak semester genap Standar Kompetensi (SK) 5. Memahami cerita tentang suatu peristiwa dan cerita pendek anak yang disampaikan secara lisan, terdiri atas dua kompetensi dasar (KD) yang meliputi 5.1 Menanggapi 


\section{BESTARI}

Vol. 16, No. 2, 2019

p-ISSN 1907-1337; e-ISSN 2807-6532

cerita tentang peristiwa yang terjadi di sekitar yang disampaikan secara lisan dan 5.2 Mengidentifikasi unsur cerita (tokoh, tema, latar, amanat). (Depdiknas, 2006: 17)

Ada berbagai macam tujuan menyimak, tujuan menyimak diantaranya meliputi: (1) menyimak untuk belajar, (2) menyimak untuk menikmati, (3) menyimak untuk mengevaluasi, (4) menyimak untuk mengapresiasi, (5) menyimak untuk mengomunikasikan ide-ide, (6) menyimak untuk membedakan bunyi-bunyi, (7) menyimak untuk memecahkan masalah, dan (8) menyimak untuk meyakinkan (Tarigan, 2008: 61-62).

1) Menyimak untuk Belajar

Sebagian orang melakukan kegiatan menyimak agar dapat memperoleh pengetahuan dari bahan ujaran pembicara. Hal ini merupakan bentuk tujuan menyimak untuk belajar (Tarigan, 2008: 60).

2) Menyimak untuk Menikmati

Menyimak untuk memahami mempunyai arti bahwa kegiatan menyimak ditekankan pada kegiatan menikmati matei yang diujarkan atau yang disimak. Menyimak semacam ini banyak dilakukan di bidang seni. Dengan kata lain, kegiatan menyimak dilakukan untuk menikmati keindahan audial (Tarigan, 2008: 60).

3) Menyimak untuk Mengevaluasi

Menyimak untuk mengevaluasi merupakan tujuan menyimak untuk menilai apa yang disimak. Penilaian itu berupa baik-buruk, indah-tidak indah, tepat-tidak tepat, logis tidak logis, dan lain-lain (Tarigan, 2008: 60).

\section{4) Menyimak untuk Mengapresiasi}

Salah satu tujuan menyimak adalah untuk menikmati dan menghargai sesuatu yang disimaknya. Tujuan menyimak semacam itu merupakan menyimak untuk mengapresiasi materi simakan (Tarigan, 2008: 61).

5) Menyimak untuk Mengomunikasikan Ide-ide

Sebagian orang menyimak bermaksud agar dapat mengomunikasikan ide-ide, gagasan-gagasan, atau perasaan-perasaan kepada orang lain dengan lancar dan tepat. Hal itu merupakan bahan penting sebagai penunjang dalam menyampaikan ide-idenya sendiri (Tarigan, 2008: 61).

6) Menyimak untuk Membedakan Bunyi-bunyi

Tujuan menyimak yang lain adalah agar dapat membedakan bunyibunyi dengan tepat, bunyi yang membedakan arti (distingtif) dan bunyi yang tidak membedakan arti. Hal ini terlihat nyata pada seseorang yang 
sedang belajar bahasa asing ketika mendengarkan bunyi ujaran penutur asli (native speaker) (Tarigan, 2008: 61).

\section{7) Menyimak untuk Memecahkan Masalah}

Tujuan kegiatan menyimak dengan maksud agar dapat memecahkan masalah secara kreatif dan analisis, sebab dari kegiatan menyimak dapat diperoleh banyak masukan berharga (Tarigan, 2008: 61).

8) Menyimak untuk Meyakinkan

Selain tujuan-tujuan yang dijelaskan di atas, ada tujuan menyimak untuk meyakinkan diri terhadap suatu masalah atau pendapat yang sebelumnya diragukan, dengan kata lain menyimak dilakukan secara persuasif (Tarigan, 2008: 61).

Tujuan menyimak di atas dapat disimpulkan bahwa tujuan menyimak adalah untuk memahami pesan dari materi yang disimak, belajar mengevaluasi, mengapresiasi, serta untuk mendapatkan hiburan. Siswa memahami bahan simakan bertujuan untuk memperoleh fakta dari apa yang disimaknya tersebut.

a. Ragam Menyimak

Tarigan (2008: 38) membagi menyimak menjadi menyimak ekstensif dan intensif.

1) Menyimak Ekstensif

Menyimak ekstensif (extensive listening) adalah sejenis kegiatan menyimak mengenai hal-hal yang lebih umum dan lebih bebas terhadap suatu ujaran, tidak diperlukan bimbingan langsung dari seorang guru. Menyimak ekstensif ini dibagi lagi menjadi beberapa bentuk, yaitu: (1) menyimak sosial, (2) menyimak sekunder, (3) menyimak estetik, dan (4) menyimak pasif (Tarigan, 2008: 38-41).

\section{2) Menyimak intensif}

Jika menyimak ekstensif lebih diarahkan pada kegitan menyimak secara lebih bebas dan lebih umum serta tidak perlu di bawah bimbingan langsung, menyimak intensif diarahkan pada suatu kegiatan yang lebih diawasi, dikontrol terhadap satu hal tertentu. Menyimak intensif meliputi: (1) menyimak kritis, (2) menyimak konsentratif, (3) menyimak kreatif, (4) menyimak eksploratif, (5) menyimak interogatif, (6) menyimak selektif) (Tarigan, 2008: 44-53).

b. Indikator Keberhasilan Menyimak

Indikator keberhasilan dalam keterampilan menyimak cerita (Nugraheni 2014: 7) meliputi:

1) Kemampuan menyimak yang terdiri dari mendengarkan, memperhatikan, memahami dan menanggapi 


\section{BESTARI}

Vol. 16, No. 2, 2019

p-ISSN 1907-1337; e-ISSN 2807-6532

2) Kemampuan dalam memahami ide pokok

3) Kemampuan dalam memahami maksud tersirat dan tersurat

4) Kemampuan dalam menceritakan kembali

5) Kemampuan dalam menjawab pertanyaan.

Dalam pembelajaran ini siswa dikatakan tuntas, jika siswa telah memahami pelajaran yang telah diberikan secara tuntas dan siswa tersebut mempunyai KKM (Kriteria Ketuntasan Minimal) lebih dari satu atau sama dengan 75. Sedangkan belajar tuntas secara keseluruhan ditentukan apabila lebih $75 \%$ dari jumlah siswa mendapatkan nilai hasil belajar $\geq 75$.

\section{Konsep Hasil Belajar}

Hasil belajar adalah suatu hasil nyata yang dicapai oleh siswa dalam usaha menguasai kecakapan jasmani dan rohani di sekolah. Hasil belajar menurut Winkel adalah keberhasilan yang dicapai oleh siswa yakni prestasi belajar siswa di sekolah yang diwujudkan dalam bentuk angka (Rusman, 2015: 14).

Hasil belajar adalah "penguasaan pengetahuan atau keterampilan yang dikembangkan oleh mata pelajaran, lazimnya ditunjukan dengan nilai tes atau angka nilai yang diberikan oleh guru" (Depdiknas, 2006: 391).

Menurut Rusman (2015: 67) secara garis besar faktor-faktor yang mempengaruhi hasil belajar siswa dibedakan menjadi 2 jenis, yaitu:

1) Faktor Internal, yaitu faktor-faktor yang bersumber dari dalam diri manusia yang dapat diklasifikasikan menjadi 2, yakni faktor biologis dan faktor psikologis.

2) Faktor eksternal, yaitu faktor yang bersumber dari luar diri manusia yang dapat diklasifikasikan menjadi 2 juga, yakni faktor human dan faktor non human, seperti alam benda, hewan dan lingkungan fisik.

Menurut Kamal (2006) hasil belajar yang dicapai oleh siswa dipengaruhi oleh faktor-faktor beriut ini:

1) Tujuan

Tujuan adalah pedoman, sekaligus sebagai sasaran yang akan dicapai dalam kegiatan belajar mengajar. Tercapainya tujuan berarti keberhasilan dalam pengajaran (Kamal, 2006: 49).

2) Guru

Pandangan guru terhadap siswa akan mempengaruhi kegiatan belajar mengajar di kelas. Guru memandang siswa sebagai makhluk 
individual dengan segala perbedaannya, akan berbeda dengan guru yang memandang siswa sebagai makhluk sosial (Kamal, 2006: 52).

3) Siswa

Keberhasilan siswa yang beraneka ragam mempengaruhi kegiatan belajar mengajar berikut hasil dari kegiatan itu sendiri, yaitu keberhasilan belajar mengajar (Kamal, 2006: 51).

\section{4) Kegiatan Pengajaran}

Pola umum kegiatan pengajaran adalah terjadinya interaksi antara guru dan siswa, dengan bahan sebagai perantaranya. Strategi penggunaan metode mengajar amat menentukan kualitas hasil belajar mengajar (Kamal, 2006: 52).

\section{5) Bahan dan alat evaluasi}

Bahan evaluasi adalah suatu bahan yang terdapat dalam kurikulum yang sudah dipelajari oleh siswa, guna kepentingan ulangan. Masingmasing alat evaluasi tersebut mempunyai kelebihan dan kekurangan, maka dalam prakteknya sering merupakan penggabungan lebih dari satu alat evaluasi (Kamal, 2006: 52).

\section{6) Suasana evaluasi}

Pelaksanaan evaluasi biasanya dilaksanakan di dalam kelas dengan melibatkan seluruh siswa, dengan dipantau oleh para pengawas. Selama pelaksanaan evaluasi selama itu pula pengawas mengamati semua sikap, tingkah laku yang dilakukan oleh siswa. Namun, dalam kenyataannya sikap pengawas berbeda-beda, ada yang ketat dan ada yang longgar dan sikap siswa pun berbeda-beda juga, ada yang jujur dan ada yang tidak sehingga ada yang berani mencontek atau minta bantuan kepada temantemannya (Kamal, 2006: 53).

\section{Konsep Strategi Omaggio}

"Strategi Omaggio" yaitu strategi pembelajaran menyimak yang dicetuskan oleh Alice Omaggio Hedley dalam bukunya Teaching and Language in Context tahun 2001 (edisi ketiga), strategi ini merupakan strategi yang meliputi beberapa langkah ini digunakan oleh Omaggio dalam pembelajaran menyimak di sekolah, langkah-langkah tersebut sudah berkembang menjadi sebuah metode. Akan tetapi, dalam penelitian ini tetap menggunakan kata strategi yaitu "strategi Omaggio".

Langkah-langkah dalam "strategi Omaggio" lebih lanjut dijelaskan oleh Sri Pujiastuti dalam Strategi Pembelajaran Bahasa (2007) yang meliputi: (1) mengecek pemahaman, (2) dikte, (3) menyimak selektif, dan (4) membuat ringkasan.

a. Kelebihan Strategi Omaggio 


\section{BESTARI}

Vol. 16, No. 2, 2019

p-ISSN 1907-1337; e-ISSN 2807-6532

Setiap strategi memiliki kelebihan dan kekurangan. Ada beberapa kelebihan dari "strategi Omaggio" yaitu:

1) Pembelajaran terasa bermakna bagi guru dan siswa.

2) Siswa menjadi terlatih daya ingatnya dalam menyimak cerita.

3) Siswa mampu merangkai kata dengan ungkapan kalimat sendiri.

4) Meningkatkan perhatian siswa kepada pembelajaran di kelas.

5) Siswa mempunyai ingatan jangka panjang terhadap cerita yang sudah disimak di kelas.

b. Kekurangan Strategi Omaggio

Di samping kelebihan dari strategi ini, ada beberapa kekurangan yang dimiliki dari "strategi Omaggio" yaitu:

1) Memerlukan bimbingan yang khusus dalam melakukan kegiatan pembelajaran, dikarenakan proses yang cukup panjang.

2) Siswa memiliki minat yang berbeda ketika melakukan kegiatan menyimak.

3) Strategi yang ini cenderung baik dan efektif digunakan di kelas tinggi saja.

c. Langkah-langkah "strategi Omaggio"

Sri Pujiastuti dalam Strategi Pembelajaran Bahasa (2007). Penerapan langkah-langkah "strategi Omaggio", dalam strategi ini diharapkan mampu melatih siswa dalam memahami bahan simakan. Berikut ini adalah penjabaran dari langkah-langkah tersebut:

1) Mengecek pemahaman dilakukan untuk mengetahui pemahaman siswa terhadap cerita rakyat yang disimak. Pemahaman tersebut berupa pemahaman terhadap unsur-unsur instrinsik cerita rakyat yang diperdengarkan. Dalam hal ini siswa diberikan pertanyaan secara lisan dengan cara tanya jawab terkait cerita tersebut.

2) Dikte dilakukan oleh beberapa siswa secara bergantian. Siswa mendiktekan hasil simakan kepada teman-temannya, sementara siswa yang lain menuliskan di buku catatan.

3) Menyimak selektif dilakukan siswa dan dibantu oleh guru menyeleksi hasil simakan cerita rakyat yang diperoleh kemudian bersama-sama membandingkan dengan hal yang relevan.

4) Dalam membuat ringkasan cerita rakyat, siswa dibebaskan menggunakan bahasa sendiri. Ringkasan yang dibuat tidak terlalu panjang, tetapi bisa mencakup keseluruhan cerita yang diperdengarkan. 
Langkah-langkah tersebut dalam penelitian ini diterapkan dalam pembelajaran menyimak cerita rakyat di kelas V Madrasah Ibtidaiyah Thoriqun Najah. Tindakan yang diberikan sebanyak 4 kali pertemuan, waktu masing-masing pertemuan disamakan dengan 1 kali pertemuan di kelas (2 x 35 menit).

\section{METODE}

Metode penelitian yang digunakan dalam penelitian ini adalah metode Penelitian Tindakan Kelas (PTK), karena masalah yang diteliti yaitu masalah yang terjadi di dalam kelas dan dirasakan langsung oleh guru yang bersangkutan sehingga sulit dibenarkan jika ada anggapan bahwa permasalahan dalam kelas diperoleh dari persepsi atau lamunan seorang peneliti.

Sebagaima dijelaskan oleh Arikunto (2009: 16) bahwa, "Penelitian Tindakan Kelas (PTK) merupakan suatu pencermatan terhadap kegiatan belajar berupa sebuah tindakan, yang sengaja dimunculkan dan terjadi dalam sebuah kelas secara bersama”.

Tindakan yang dilakukan menunjuk pada suatu siklus kegiatan yang sengaja direncanakan dengan tujuan untuk memperbaiki kinerja, sifatnya kontekstual dan hasilnya tidak untuk digeneralisasikan.Rangkaian siklus ini dirancang dan ditujukan untuk kegiatan siswa secara aktif.Dalam membuat atau menyusun rangkaian siklus terdapat langkah-langkah yang harus dilaksanakan, yaitu perencanaan, pelaksanaan, pengamatan dan refleksi.

\section{HASIL DAN PEMBAHASAN}

\section{Hasil Penelitian}

Penelitian dilaksanakan selama dua siklus setiap siklusnya dilakukan dua kali pertemuan, setiap siklus terdiri dari empat tahap, yaitu perencanaan, pelaksanaan, pengamatan, dan refleksi. Pembelajaran siklus I ini dimulai pada hari Senin tanggal 17 April 2017 dan hari Selasa 18 April 2017. Tujuan pembelajaran yang hendak dicapai dalam pelaksanaan pembelajaran siklus I ini adalah siswa dapat mendengarkan cerita melalui audio. Siswa dapat melakukan tanya jawab (diskusi) tentang unsur-unsur cerita yang disimak. Siswa dapat menceritakan kembali isi cerita melalui tulisan dengan bahasa sendiri. Hasil pengamatan pada siklus I pertemuan kesatu dapat diketahui bahwa untuk kemampuan guru dalam merancang RPP mencapai rata-rata 90,1; kemampuan guru dalam mengajar mencapai nilai rata-rata 90,66; dan hasil belajar siswa mencapai nilai rata-rata 71,42 (47,61\%). Hasil pengamatan pada siklus I pertemuan kedua dapat diketahui bahwa untuk kemampuan guru dalam merancang RPP mencapai rata-rata 91,85; 


\section{BESTARI}

Vol. 16, No. 2, 2019

p-ISSN 1907-1337; e-ISSN 2807-6532

kemampuan guru dalam mengajar mencapai nilai rata-rata 92,00; dan hasil belajar siswa mencapai nilai rata-rata 74,00 (61,90 \%).

Berdasarkan dari hasil observasi selama berlangsungnya proses pembelajaran pada siklus I, terdapat permasalahan yang menjadi kendala dalam pembelajaran. Permasalahan tersebut diantaranya penyusunan Rencana Pelaksanaan Pembelajaran (RPP) harus lebih diperhatikan secara teliti, Kurangnya penguasaan materi pembelajaran, dalam menyampaikan langkah-langkah pembelajaran, penggunaan kata-kata, test penilaian kurang disesuaikan dengan strategi, guru harus belum terlihat aktif dan kreatif dan guru masih perlu menambah sumber belajar yang relevan.

Peneliti menetapkan pelaksanaan tindakan siklus kedua pada hari Selasa, tanggal 25 April 2017 dan hari Rabu, tanggal 26 April 2017 dengan materi unsur-unsur ceita. Pembelajaran tindakan siklus kedua disusun berdasarkan hasil evaluasi dan refleksi yang dilakukan pada tindakan siklus pertama. Tujuan pembelajaran yang hendak dicapai dalam pelaksanaan pembelajaran siklus II adalah siswa dapat melakukan tanya jawab (diskusi) tentang unsur-unsur cerita yang disimak. Siswa dapat menyebutkan unsur-unsur cerita. Siswa dapat menceritakan kembali isi cerita melalui tulisan dengan bahasa sendiri. Hasil pengamatan pada siklus II pertemuan ketiga dapat diketahui bahwa untuk kemampuan guru dalam merancang RPP mencapai rata-rata 93,50; kemampuan guru dalam mengajar mencapai nilai rata-rata 94,44; dan hasil belajar siswa mencapai nilai rata-rata $78,57(80,95 \%)$. Hasil pengamatan pada siklus II pertemuan keempat dapat diketahui bahwa untuk kemampuan guru dalam merancang RPP mencapai rata-rata 96,15; kemampuan guru dalam mengajar mencapai nilai rata-rata 97,22; dan hasil belajar siswa mencapai nilai rata-rata 82,19 (90,47\%).

\section{Pembahasan}

Penelitian tindakan kelas ini dilaksanakan sebanyak 2 siklus, satu siklus dilaksanakan dua kali pertemuan. Penelitian ini telah dilaksanakan di kelas V MIS Thoriqun Najah Kecamatan Sukadana Kabupaten Ciamis pada semester II tahun pelajaran 2016/2017.

Berdasarkan hasil penelitian tindakan kelas yang telah dilaksanakan dengan menggunakan "strategi Omaggio" untuk meningkatkan hasil belajar siswa pada mata pelajaran Bahasa Indonesia aspek menyimak pokok bahasan unsur-unsur cerita di kelas V MIS Thoriqun Najah Kecamatan Sukadana Kabupaten Ciamis pada pembelajaran siklus I dan II maka dapat diketahui:

1) Penyusunan Rencana Pelaksanaan Pembelajaran (RPP) sudah meningkat, berdasarkan penilaian yang dilakukan obsever dalam 
penyusunan RPP dari siklus ke siklus mengalami peningkatan. Hal itu dapat dilihat dari hasil observasi siklus I pada pertemuan kesatu dengan nilai rata-rata 90,10 dan pertemuan kedua dengan nilai ratarata 91,85. Siklus II pada pertemuan ketiga dengan nilai rata-rata 93,50 dan pertemuan keempat dengan nilai rata-rata mencapai 96,15.

2) Kinerja guru dalam melaksanakan pembelajaran juga mengalami peningkatan. Dari dua siklus yang telah dilaksanakan dalam penelitian tindakan kelas ini, pelaksanaan pembelajaran semakin baik, hal ini dilihat berdasarkan penilaian observer pada pembelajaran siklus I pada pertemuan kesatu dengan nilai rata-rata 90,66 dan pertemuan kedua dengan nilai rata-rata 92,00. Siklus II pada pertemuan ketiga dengan nilai rata-rata 94,44 dan pertemuan keempat dengan nilai rata-rata 97,22.

3) Hasil belajar siswa pada pembelajaran Bahasa Indonesia aspek menyimak dengan menggunakan "strategi Omaggio" juga mengalami peningkatan. Berdasarkan penelitian tindakan kelas yang telah dilakukan hasilnya semakin meningkat. Hal itu terlihat dari hasil tes belajar siswa siklus I pada pertemuan kesatu dengan rata-rata nilai 71,42 pada perhitungan 10 orang yang tuntas dan 11 orang yang belum tuntas dari nilai KKM yang telah ditentukan, pada pertemuan kedua dengan rata-rata nilai 74,00 pada perhitungan 13 orang yang tuntas dan 8 orang yang belum tuntas dari nilai KKM yang telah ditentukan. Dan siklus II pada pertemuan ketiga dengan rata-rata nilai 78,57 pada perhitungan 17 orang yang tuntas dan 4 orang yang belum tuntas dari nilai KKM yang telah ditentukan, pada pertemuan keempat dengan rata-rata nilai 82,19 pada perhitungan 19 orang yang tuntas dan 2 orang yang belum tuntas dari nilai KKM yang telah ditentukan.

Untuk memudahkan memahami hasil kinerja guru dalam menyusun Rencana Pelaksanaan Pembelajaran (RPP), kinerja guru dalam melaksanakan pembelajaran, dan peningkatan hasil belajar peserta didik yang sudah dilakukan oleh peneliti dari siklus I sampai siklus II pada penelitian tindakan kelas yang dilakukan di kelas V MIS Thoriqun Najah Kecamatan Sukadana Kabupaten Ciamis pada mata pelajaran Bahasa Indonesia aspek menyimak pokok bahasan unsur-unsur cerita, berikut ini penelti sajikan hasilnya dalam gambar diagram batang sebagai berikut:

Gambar Diagram Hasil Penelitian 


\section{BESTARI}

Vol. 16, No. 2, 2019

p-ISSN 1907-1337; e-ISSN 2807-6532

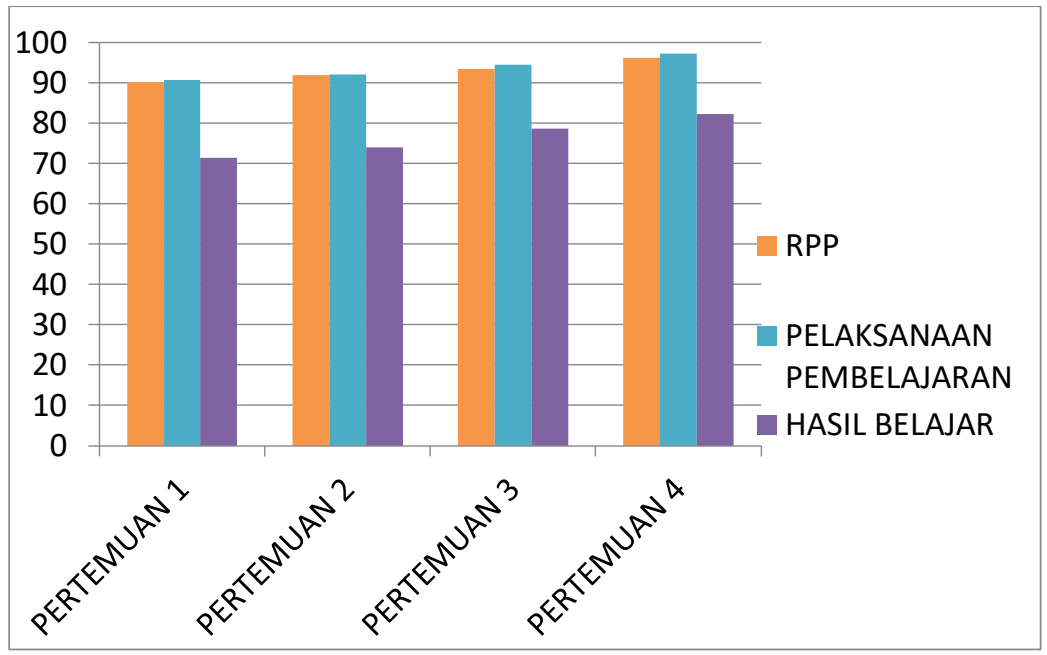

Dengan demikian dapat disimpulkan, bahwa dengan digunakannya "strategi Omaggio" di kelas V MIS Thoriqun Najah Kecamatan Sukadana Kabupaten Ciamis pada mata pelajaran Bahasa Indonesia aspek menyimak pokok bahasan unsur-unsur cerita dapat meningkatkan hasil belajar siswa.

\section{SIMPULAN}

Berdasarkan penelitian yang telah dilakukan dan analisa yang telah peneliti kemukakan pada pembahasan sebelumnya, dengan berpijak pada perumusan masalah. Maka dapat diambil kesimpulan sebagai berikut:

1. Penyusunan Rencana Pelaksanaan Pembelajaran (RPP) pembelajaran Bahasa Indonesia pokok bahasan unsur-unsur cerita dengan menggunakan "strategi Omaggio" untuk meningkatkan hasil belajar siswa di kelas V MIS Thoriqun Najah Kecamatan Sukadana Kabupaten Ciamis tahun pelajaran 2016/2017 yang dilaksanakan oleh peneliti sangat baik, hasil ini berdasarkan penilaian observer terhadap kinerja peneliti dalam penyusunan RPP mengalami grafik yang meningkat. Hal itu dapat dilihat dari hasil observasi siklus I pada pertemuan kesatu dengan nilai rata-rata 90,10 dan pertemuan kedua dengan nilai rata-rata 91,85. Siklus II pada pertemuan ketiga dengan nilai rata-rata 93,50 dan pertemuan keempat dengan nilai rata-rata mencapai 96,15 .

2. Upaya guru dalam melaksanakan pembelajaran Bahasa Indonesia pokok bahasan unsur-unsur cerita dengan menggunakan "strategi Omaggio" untuk meningkatkan hasil belajar siswa di kelas V MIS Thoriqun Najah Kecamatan Sukadana Kabupaten Ciamis tahun pelajaran 2016/2017 ternyata berhasil meningkatkan keaktifan siswa 
dalam mengikuti pembelajaran. Ini dapat telihat dari hasil observasi kemampuan guru dalam melakukan pembelajaran setiap siklusnya. Hasil penilaian observer terhadap kemampuan guru dalam melaksanakan pembelajaran siklus I pada pertemuan kesatu dengan nilai rata-rata 90,66 dan pertemuan kedua dengan nilai rata-rata 92,00. Siklus II pada pertemuan ketiga dengan nilai rata-rata 94,44 dan pertemuan keempat dengan nilai rata-rata 97,22.

3. Peningkatan hasil belajar siswa pada pembelajaran Bahasa Indonesia pokok bahasan unsur-unsur cerita dengan menggunakan "strategi Omaggio" untuk meningkatkan hasil belajar siswa di kelas V MIS Thoriqun Najah Kecamatan Sukadana Kabupaten Ciamis tahun pelajaran 2016/2017 dapat dikatakan berhasil meningkatkan hasil belajar siswa. Berdasarkan tes hasil belajar siswa pada setiap siklusnya mengalami grafik yang meningkat. Hasil tes belajar siswa siklus I pada pertemuan kesatu dengan rata-rata nilai 71,42 pada perhitungan 10 orang yang tuntas dan 11 orang yang belum tuntas dari nilai KKM yang telah ditentukan, pada pertemuan kedua dengan rata-rata nilai 74,00 pada perhitungan 13 orang yang tuntas dan 8 orang yang belum tuntas dari nilai KKM yang telah ditentukan. Dan siklus II dengan rata-rata nilai 78,57 pada perhitungan 17 orang yang tuntas dan 4 orang yang belum tuntas dari nilai KKM yang telah ditentukan, pada pertemuan keempat dengan rata-rata nilai 82,19 pada perhitungan 19 orang yang tuntas dan 2 orang yang belum tuntas dari nilai KKM yang telah ditentukan.

\section{DAFTAR PUSTAKA}

Arikunto, Suharsimi. (2006). Penelitian Tindakan Kelas. Jakarta: PT. Bumi Aksara.

BSNP. 2006. Standar Isi Standar Kompetensi dan Kompetensi Dasar Kurikulum Tingkat Satuan Pendidikan Jenjang Pendidikan Sekolah Dasar. Jakarta: Badan Standar Nasional Pendidikan. -- (2006). Kurikulum Satuan Pendidikan. Jakarta: Depdiknas.

Fathul Wahid. (2008). Pemberdayaan Pendidikan Islam Merespon Perkembangan Teknologi Informasi. http://journal.uii.ac.id/index. php /JPI/ article/ viewFile/ 189/ 178 diunduh pada 2 Januari 2017.

Hidayah, Aprilia. (2010). Keefektifan Metode Snowball Throwing terhadap Kemampuan Menyimak Berita Siswa Kelas VII SMP N 5 Depok, Sleman. Yogyakarta: Pendidikan Bahasa dan Sastra Indonesia, FBS Universitas Negeri Yogyakarta.

Kamal, Mustofa. (2006). Buku Ajar Strategi mengajar untuk Fakultas Tarbiyah. IAID Ciamis. 


\section{BESTARI}

Vol. 16, No. 2, 2019

p-ISSN 1907-1337; e-ISSN 2807-6532

Musfiroh, Tadkiroatun dan Rahayu, Dwi Hanti. 2004. Menyimak Komprehensif dan Kritis. Yogyakarta: Universitas Negeri Yogyakarta.

Nugraheni, Surya Fatria (2014). Peningkatan Keterampilan Menyimak Cerita. Naskah Publikasi UMS, 1-15.

Omaggio, Alice. (2001). Teaching and Language In Context. U.S.A: Wendy Nelson.

Pujiastuti, Sri. (2007). Strategi Pembelajaran Bahasa. Yogyakarta: Universitas Negeri Yogyakarta.

Pusat Bahasa. (2011). Kamus Besar Bahasa Indonesia Online. http:// kamusbahasaindonesia. org/ diunduh 1 Januari 2017.

Resmini, Novi. (2002). Prinsip Dasar Pembelajaran Bahasa Indonesia. Bandung: Universitas Pendidikan Indonesia.

Rusman, (2015). Pembelajaran Tematik Terpadu. Jakarta: PT. Rajagafindo.

Sutari, Ice at.al.. (2000). Menyimak. Jakarta: Depdikbud.

Soeparno. (2002) Dasar-dasar Linguistik.Yogyakarta: PT. Tiara Wacana Yogya.

Tarigan, Henry Guntur. (2008). Menyimak Sebagai Suatu Keterampilan Berbahasa. Bandung: Angkasa.

Thoyyar, Husni., at.al. (2016). Pedoman Penulisan Skripsi dan Artikel Ilmiah. Ciamis: Institut Agama Islam Darussalam. 
